Marcin Czardybon

Uniwersytet Warszawski

\title{
O duchu (brexitu). Z dodatkiem uwag o tymotycznej stymulacji narodu w najnowszej polskiej literaturze
}

\author{
W ogóle ten duch [...] jest jegomościa wysoce podejrzanym, \\ dlatego też powinniśmy żądać od niego paszportu wszędzie, \\ gdzie nam wejdzie w drogę.
}

A. Schopenhauer

1.

Punkt wyjścia tego szkicu stanowi pytanie: „czy duch brexitu trafił też do europejskiej prozy [i poezji - M.C.] poza Wyspami, a jeśli tak, to pod jakimi postaciami?"'. Odpowiedź na nie jest możliwa pod warunkiem wyjaśnienia sformułowania "duch brexitu”. Właściwym tropem wydaje się tu pojęcie Zeitgeist. Jak celnie zauważył Theo Jung, powoływanie się na koncepcję "ducha czasu” zakłada przynajmniej trzy aksjomaty: 1. wielość zjawisk historycznych w danym przedziale temporalnym jest scalana przez fundamentalną jedność (ducha), która podlega transformacji w czasie; 2. jedność ta przejawia się w „znakach czasu", podczas gdy inne fenomeny dziejowe pozostają drugorzędne lub całkiem nieistotne dla duchowego rozwoju epoki; 3. ten, kto formułuje twierdzenia o duchu czasu, powinien być w mocy zidentyfikować i odczytać wspomniane „znaki czasu” w odniesieniu do „kształtu” ducha danej epoki (Jung 2014: 26). Zeitgeist rozumieć można też jako rozpoznawalną ex post specyfikę okresu historycznego. Przejawia się ona w panujących $\mathrm{w}$ danym temporalnym wycinku ideach, opiniach, wierzeniach, wreszcie - w „klimacie epoki”. Skoro zaś, jak pośrednio wynika z postawionego na początku pytania, to brexit stanowić

1 Pytanie to padło w call for papers do niniejszego numeru „Porównań”. 
ma znak naszego czasu - lub oddawać klimat epoki - niezbędne jest podjęcie namysłu nad przyczynami tego zdarzenia.

Ryzykując uproszczenie, można wyróżnić dwie główne narracje dotyczące powodów referendalnej decyzji o wystąpieniu Wielkiej Brytanii z UE². Pierwsza z nich odnosi się do kwestii ekonomicznych. Według badań, odsetek zwolenników exodusu Wielkiej Brytanii z UE był wyższy na obszarach kraju znajdujących się w niekorzystnej sytuacji ekonomicznej. Co za tym idzie, o brexicie zadecydować miał głos (protestu) tych, którzy nie stali się beneficjentami boomu gospodarczego, „napędzanego tendencjami globalistycznymi - ze szczególnym uwzględnieniem integracji europejskiej”3 (Chan i in. 2020: 831). W świetle drugiej ze wzmiankowanych narracji oprócz ekonomicznego istnieje też inny, „subiektywny” lub „kulturowy” wymiar afirmatywnego stosunku części mieszkańców Wysp do perspektywy wystąpienia Wielkiej Brytanii z uE. Tu kluczowe znaczenie uzyskują kategorie narodowej tożsamości, tradycji i dumy. Ich istotność bywa łączona z zauważalną w XxI wieku tendencją do odradzania się angielskiego nacjonalizmu. Nacjonalizm ten, jak dowodzą badacze, w znacznej mierze fundowany jest na historycznych resentymentach i nostalgii ${ }^{4} \mathrm{do}$ lat imperialnej świetności (zob. Chan i in. 2020: 831). Warto także dodać, że stanowią one jednocześnie podglebie eurosceptycyzmu, czyli postawy, której korzenie w Wielkiej Brytanii, jak wskazuje np. Menno Spiering, sięgają jeszcze czasów sprzed jej przystąpienia do EWG (zob. Spiering 2014).

Podążając tropem drugiej z wymienionych interpretacji brexitu i podejmując kluczowy dla tego szkicu temat literatury, wypada zapytać o sposoby, w jakie wzmiankowana niechęć do projektu zintegrowanej Europy i nostalgiczno-resentymentalny amalgamat afektów mieszkańców Wielkiej Brytanii manifestują się na kartach powstających na Wyspach utworów. Pojawia się tu jednak kłopot. Choć literatura jest tyglem, w którym ścierają się różne światopoglądy i który zarazem stanowi istotne medium wpływu na pamięć ludzkich zbiorowości (przekładając się na ich poczucie tożsamości i - nierzadko - orientacje/

2 Kwestia brexitu dotyczy szerokiego spektrum problemów, m.in. stosunku Brytyjczyków do imigracji, suwerenności w stanowieniu praw itd. Jednakże stanowią one niejako elementy składowe wymienionych narracji.

3 Tłumaczenia tekstów obcojęzycznych, jeśli nie zaznaczono inaczej, pochodzą od autora artykułu.

4 Warto zauważyć, że nostalgia, podobnie jak melancholia, ostatecznie koncentruje się nie tyle na utraconym obiekcie, ile na samej utracie tegoż obiektu. Jak stwierdza Przemysław Czapliński, „nostalgia zostaje uruchomiona przez teraźniejszość, potem zaś żywi się sama sobą, a podsyca różnicą. [...] Nostalgik pozbawiony różnicy, cofnięty do wymarzonej przeszłości, umarłby z tęsknoty za tęsknotą" (Czapliński 20o1: 7-23). 
decyzje polityczne) (zob. Erll 2018: 249-250), sam brexit nie doczekał się wśród pisarzy wielu prominentnych, zawoalowanych lub jawnych, zwolenników ${ }^{5}$ (Self 2020). Z drugiej strony - w utworach brytyjskich autorów niechęć do kontynentalnej Europy (jak i idei europejskiej wspólnoty) jest zauważalna przynajmniej od drugiej połowy xx wieku. Niechęć ta w dużej mierze bazuje na parze określonych, przenikających się schematów narracyjnych. Pierwszy z nich eksploatuje historyczne traumy Brytyjczyków (w jego ramach np. odium nazizmu zostaje przeniesione na całą Europę). Drugi zaś, ewokując - czasem implicytnie - przeszłą imperialną potęgę, demaskuje projekt integracji europejskiej jako próbę zamachu unijnych, znajdujących się pod przemożnym wpływem Niemiec urzędników na tradycję, kulturę i wolność Wielkiej Brytanii (oraz jej mieszkańców) (zob. Spiering 2014; Eaglestone 2018: 92-104; Koegler, Malreddy, Tronicke 2020: 585-592). W różnym nasileniu oba te schematy narracyjne odnaleźć można chociażby w tekstach prozatorskich: Davida Lodge’a, Pameli Hansford Johnsson, Wilfreda Sheeda, Anthony'ego Bailey'a, Juliana Mitchella, Andrew Sinclaira, Malcolma Bradbury'ego, Thomasa Hinde'a, Dana Jacobsona, Andrew Robertsa, Angusa Wilsona, Alana Judda, Michaela Dobbsa, Kingsley'a Amisa czy Tima Parksa (zob. Spiering 2014). Z kolei np. nestor angielskiej poezji, Geoffrey Hill w zbiorze Canaan odnosił się do traktatu z Maastricht, pisząc o „poniżeniu” (Hill 1996: 30).

2.

Narracja zwolenników brexitu splata się tym samym z nieprzychylną europejskiej wspólnocie opowieścią, snutą przez kilka dziesięcioleci na kartach brytyjskiej literatury. Jednakże, powracając do kwestii Zeitgeistu, którego znakiem miała być decyzja o opuszczeniu struktur ue przez Wielką Brytanię, wypada zapytać o wydarzeniowy, a nawet symboliczny ${ }^{6}$ potencjał tego historycznego fenomenu i jego znaczenie. Podążając za rozpoznaniami Petera Sloterdijka (a zarazem je rozwijając), można stwierdzić, że ten exodus ze struktur Unii Europejskiej stanowi wydarzeniowo wyrazisty przejaw tendencji do opuszczania „kryształowego pałacu”. Czyli, według niemieckiego filozofa, europejskiej „przestrzeni wygody i bezpieczeństwa, przestrzeni ochronnej”, wreszcie - przestrzeni

5 Bywa to tłumaczone proeuropejską orientacją większości pisarzy w Wielkiej Brytanii w XxI wieku (Self 2020). Referendum z 2016 roku i dalsze jego reperkusje, postrzegane jako poważny kryzys, dały początek nurtowi literackiemu: „brexlit” (Shaw 2018: 15-31).

6 Znaki czasu odnoszą się do ducha czasu (Zeitgeistu) w taki sposób, jak symbol do tego, co jest przezeń symbolizowane. Tzn. w przeciwieństwie np. do alegorii nie tyle odsyłają, ale także współtworzą dany fenomen. 
konsumpcyjnego i socjalnego „rozpieszczenia” oraz posthistorycznej „nudy” (Sloterdijk 2011b: 211-215, 261-274). Co istotne jednak: brexit nastąpił, gdy - pod wpływem m.in. finansowych i imigracyjnych kryzysów - na „kryształowej” kopule „pałacu” zaczęly uwyraźniać się rysy (zob. Cesarz 2017: 103-119). Ekonomicznym powodom wyjścia Wielkiej Brytanii z Unii Europejskiej w ujęciu jego zwolenników, o czym już wspominałem, towarzyszyła opowieść odwołująca się do godnościowych roszczeń i resentymentalnych afektów mieszkańców byłego imperium. Brytyjska debata wokół wystąpienia ze struktur europejskiej wspólnoty została więc uzupełniona o, uwidoczniający się też w utworach literackich wymienionych wcześniej autorów, komponent tymotejski. Określenie to pochodzi od greckiego słowa thymos, rozumianego jako duma, gniew, tłumaczonego też czasem jako... duch (zob. Baran 2018: 66).

Francis Fukuyama w pracy Koniec historii i ostatni człowiek wskazywał, że thymos (sfera ludzkich gniewnych afektów i godnościowych roszczeń) oraz związane z nim "pragnienie uznania” stanowią fundament życia politycznego (zob. Fukuyama 2017: 267-273). Z kolei na kartach książki Tożsamość: współczesna polityka tożsamościowa $i$ walka o uznanie badacz ściśle powiązał kwestie ekonomicznych rozczarowań i tymotejskich roszczeń z rozwojem i powodzeniem orientacji nacjonalistycznej. Ta stanowić miała reakcję na dynamikę ekonomiczno-kulturowych zmian w nowoczesnych oraz ponowoczesnych społeczeństwach:

przejście od Gemeinschaft do Gesellschaft położyło podwaliny pod ideologię nacjonalizmu, opartą na głębokiej tęsknocie za urojoną przeszłością silnej wspólnoty [...]. Nacjonaliści mogą przełożyć utratę względnej pozycji materialnej [danej jednostki - M.C.] na utratę tożsamości i statusu: zawsze byłeś ważnym członkiem naszego wielkiego narodu, ale obcokrajowcy, imigranci i twoi właśni, należący do elit współobywatele spiskowali, żeby cię uciemiężyć; twój kraj nie jest już twój, a ty nie jesteś już szanowany na własnej ziemi (Fukuyama 2019: 88-117).

Łatwo odnieść te słowa, co czyni również Fukuyama, do przebiegu debaty wokół brexitu - zwłaszcza splotu ekonomicznych i kulturowych argumentów stosowanego przez stronnictwo „proleavers”. W takim ujęciu pars pro toto „ciemiężycieli” mieszkańców Wielkiej Brytanii stanowi ue (wraz z jej biurokracją, legislacją, wolnym przepływem osób, usług i towarów oraz wsparciem migracyjnych i imigracyjnych fenomenów etc.)7. Także Sloterdijk - w pracy

7 Warto też przytoczyć następujące słowa Fukuyamy: „[...] jeśli się posłucha wypowiedzi zwolenników brexitu, dochodzi się do wniosku, że kontynent wciąż jest zniewolony, tym razem nie przez papieża ani cesarza, ale przez Unię Europejską" (Fukuyama 2019: 190). 
Gniew i czas - wskazywał, że tymotyczne roszczenia i strategie zarządzania nimi stanowią fundament zjawisk politycznych, a zarazem klucz do ich zrozumienia ${ }^{8}$. Według niemieckiego filozofa organizowanie "gniewnych” afektów jest możliwe za sprawą wykorzystania narzędzi retorycznych. Z kolei za esencję tymotycznej retoryki Sloterdijk uznawał wzniosłość (zob. Sloterdijk 2011a: 25-27).

Potwierdzenie przedstawionego powyżej stanowiska autora Gorliwości Boga oraz Fukuyamowskich twierdzeń o splocie ekonomicznych i godnościowych roszczeń z powodzeniem tendencji nacjonalistycznych odnaleźć można w politycznych przemówieniach zwolenników brexitu. Np. Nigel Farage, onegdaj lider eurosceptycznego ugrupowania U KIP, wystąpił w 2015 roku z następującą niewątpliwie wzniosłą ${ }^{9}$ - enuncjacją:

[...] Tak, wierzymy w Wielką Brytanię, wierzymy w Wielką Brytanię, która jest niezależna i samowładna, [...] wierzymy w Wielką Brytanię, [...] w której to my decydujemy, kto będzie pracował i mieszkał w naszym kraju, [...] wierzymy w Wielką Brytanię, w której każdy ma własne sposoby, by dać sobie radę i osiągnąć sukces, wierzymy w Wielką Brytanię, która opowiada się za wartościami sprawiedliwości. [...] Wierzymy w Wielką Brytanię, która odrodzi się w świecie. [...] Wierzymy w Wielką Brytanię, ponieważ wierzymy w ten naród (Farage 2015).

3 .

Także w Polsce zauważalna jest radykalizacja nastrojów nieprzychylnych Unii Europejskiej ${ }^{10}$. Co więcej - również w przypadku mieszkańców Rzeczypospolitej niechęć ta artykułowana jest w literaturze pięknej (jak i w politycznych przemowach - zob. Łabędź 2017: 165) przy użyciu uwznioślających zabiegów retorycznych. Ich celem, do czego powrócę, jest aktywizacja tymotycznych roszczeń i resentymentalnych afektów Polaków. Okoliczność ta wskazuje, że na pytanie o obecność w literaturze Starego Kontynentu (poza Wyspami) „ducha brexitu”, rozumianego jako zabarwiona godnościowo niechęć do „zamieszkiwania”

8 Podobnie u Axela Honnetha (Honneth 2012: 160-161).

9 Wzniosłość ta w dużej mierze opiera się na eksploatacji zabiegów repetitio i uwypuklenia (a więc zabiegów amplifikacyjnych). Do kwestii tej powrócę.

10 Nota bene, niechęć do UE - również w literaturze - zauważalna była w Polsce jeszcze przed jej przystąpieniem do UE. Na niwie literackiej przejawiała się ona wówczas głównie - podobnie zresztą jak w Wielkiej Brytanii - w powieściach sF, np. tych pióra Rafała Ziemkiewicza, Rafała Stradomskiego, Joanny Rudniańskiej etc. (Czapliński 2011). 
w europejskim, nieco podupadającym „kryształowym pałacu”, należy odpowiedzieć twierdząco. Duch ten w polskiej literaturze pięknej najpełniej przejawia się w pracach pisarzy sytuujących się lub sytuowanych blisko środowiska rodzimej prawicy (m.in. w tekstach Jarosława Marka Rymkiewicza, Jana Polkowskiego, Przemysława Dakowicza, Krzysztofa Koehlera i Wojciecha Wencla).

Dostrzegalna jest tu wszakże różnica. O ile na Wyspach zarzut opresyjności artykułowany był względem uE często w utworach zaliczanych do literatury popularnej, o tyle „obrona” polskości przed „eurokołchozowym” (sic!) dyktatem („proniemieckich” itd. „eurokratów”) znajduje na niwie pisarskiej swój wyraz raczej w kunsztownych, erudycyjnych poetyckich oraz prozatorskich tekstach, obficie czerpiących głównie z tradycji romantycznej i w tym też, romantycznym, paradygmacie konsekwentnie tematyzujących dziejowe traumy mieszkańców Rzeczypospolitej (zob. Czardybon 2018: 213-227). Nie zmienia to faktu, że także w przypadku rodzimej literatury daje się zauważyć tendencję do wykorzystywania przenikających się nawzajem, analogicznych do brytyjskich eurosceptycznych schematów narracyjnych. Pierwszy z nich odnosi się do podnoszenia historycznych (głównie antyniemieckich) resentymentów mieszkańców Rzeczypospolitej. Drugi zaś ukazuje uE en bloc jako twór wrogi polskiej tradycji i tożsamości.

Dobrą egzemplifikację tego fenomenu stanowią dygresyjne fragmenty sylwicznej opowieści Rymkiewicza o powstaniu warszawskim, ukazywanym przezeń jako „największe wydarzenie w historii Polaków” - Kinderszenen. Poeta z Milanówka na kartach swojego utworu dezawuuje m.in. samą ideę europejskiej wspólnoty. Wskazuje bowiem na domniemaną ciągłość pomiędzy zdominowaną przez niemiecką gospodarkę współczesną UE a pomysłami... Hansa Franka. W obu przypadkach Polakom przypadać ma - według Rymkiewicza - miejsce wyrobników germańskiego hegemona:

[...] Frank dał wyraz przekonaniu, że przyszła niemiecka Europa musi być Europą współpracy [...]. Dobrze więc rozumiał, że losy Trzeciej Rzeszy są już przesądzone i że trzeba coś teoretycznie wymyślić na przyszłość. Trzeba jednak przyznać, [...] że [...] mamy w tym wypadku do czynienia z czymś w rodzaju proroctwa. Takiego w dodatku, które się sprawdziło, które sprawdza się na naszych oczach. Proroctwa mówiącego, że Polacy, jako [...] siła godna zaufania, [...] wreszcie przydadzą się na coś Europie i swoją pracą będą wspierać właśnie ten porządek, który zaprowadzą w niej Niemcy. [...] Polacy [...] mogliby [...] jakoś przetrwać, istnieć nadal - gdyby tylko zechcieli włączyć się w historię Europy i uczestniczyć w historii wspólnej. Takie włączenie się w historię wspólną, której uczestnikami głównymi byliby Niemcy, nie oznaczałoby 
więc całkowitej anihilacji Polaków - mogliby oni zachować (zapewne tylko na jakiś czas) swoją szczególność, swój sposób życia, nawet coś ze swojej kultury. Trzeba by tylko to wszystko postawić na usługi Europy [...] (Rymkiewicz 2008: 79-82).

Dakowicz wykłada z kolei, że UE:

oferuje nam wyrazisty projekt tzw. nowoczesności, na przyjęcie którego nie jesteśmy po prostu gotowi. Największe liberalne dziwactwa są u nas traktowane niczym prawda objawiona. [...] Unijna uniformizacja (prawna, budżetowa, kulturowa) przyczynia się de facto do konserwacji nieszczęsnego stanu postkomunistycznej przejściowości (Dakowicz 2014: 21-22).

Polkowski, chociażby w wierszach z tomu Gorzka godzina, boleje nad „czasem marnym” kulturowego upadku przenikniętej konsumpcjonizmem, „dotkniętej multikulturowością” współczesnej zintegrowanej zachodniej Europy („Za garbem słońca klęczy Rzym / Tkwi oścień Moschea di Roma / Embrion Europy szepcze hymn / Lecz jego śmierć już jest bezdomna [...] / Mówił poeta i szedł za nim / Złoty drapieżnik - cielec ciszy"), przeciwstawiając tej rzekomej degrengoladzie wierność wypracowywanej w dziejowych zawieruchach polskiej tradycji (w tym językowi) i katolickiej wierze (Polkowski 2015: 9). Wencel zaś, po części za Janem Pawłem II, kontrastuje polskość i - w domyśle zachodnioeuropejską - „cywilizację śmierci” „wyznawców boga umarłych” (Wencel 2016: 36, 38). Zbliżone treści można także wyczytać m.in. w tekstach Koehlera, Bronisława Wildsteina etc.

Już część powyższych przykładów cechuje wzniosły ton, często powracający w pracach literackich polskich „eurosceptycznych” pisarzy. Jako dobitną egzemplifikację tej predylekcji do „wznoszenia” rozpisanych na prozę i wiersze opowieści, stanowiących afirmację narodowego bytu i przynależenia doń, a zarazem organizujących resentymentymentalne pokłady obecne wśród mieszkańców III RP, warto przytoczyć też chociażby następujące fragmenty przywoływanych już wcześniej Kinderszenen Rymkiewicza ${ }^{11}$ :

Powstanie Warszawskie było największym wydarzeniem w historii Polaków - w całej naszej historii nie było (i pewnie nigdy już nie będzie) większego wydarzenia. $Z$ tego największego wydarzenia w naszej

11 Uprzywilejowanie twórczości Rymkiewicza w tym szkicu da się usprawiedliwić nader silną pozycją pisarza wśród polskich prawicowych literatów. 
historii wynikają też różne wielkie nauki - potrzeba będzie jeszcze wielu dziesięcioleci, wielu stuleci, żeby się z nimi zapoznać, żeby je przemyśleć i dobrze zrozumieć (Rymkiewicz 2008: 141);

[...] to była klęska, katastrofa, jakaś złowieszcza zapowiedź końca. Taka zapowiedź, która mówiła, że Polacy już się z tego nie podniosą i że Polaków już nie będzie, bo nie starczy ich na to, żeby była Polska. Klęska, ale taka, której nie da się porównać z żadną inną, taka, jakiej Polacy nigdy jeszcze nie ponieśli, największa z dotychczasowych. [...] Ale minęło ponad pół wieku i okazało się, że [...] ta dziejowa wieszczba okazała się pomyłką. Dlaczego? Dlatego, że Powstanie zwyciężyło. Dowód na to, dobrze widoczny, całkowicie wystarczający, jest tuż obok, wokół nas - i my wszyscy, którzy teraz tu żyjemy, też jesteśmy tym dowodem. Tym dowodem jest niepodległa Polska (Rymkiewicz 2008: 157);

Potężna pięść akowskich batalionów, pięść „Zośki”, „Chrobrego” i „Łukasińskiego", uderzyła w Niemców i pokazała im, kim są i co potrafią Polacy - nawet nie mając czołgów, armat, pociągów pancernych i samolotów - a skutki tego będą widoczne (w naszej narodowej psychice, a więc i w dziejowych wydarzeniach) przez stulecia. Byłoby też dobrze, żeby i Niemcy to sobie zapamiętali - na całą wieczność (Rymkiewicz 2008: 187).

Głównym retorycznym zabiegiem wykorzystanym w tych partiach Kinderszenen jest amplifikacja. W powyższych fragmentach jej funkcję stanowi uwznioślenie. Według rozpoznań Kennetha Burke’a amplifikacja jest najbardziej „radykalnym” z retorycznych zabiegów, obejmującym „szeroki zakres środków” i „zwiększającym perswazyjność wypowiedzi” - niejednokrotnie dzięki kumulacji stosowanych chwytów (Burke 1969: 69). W powyższych wyimkach Kinderszenen na plan pierwszy wysuwają się: powtórzenia, zdania pytające, zaprzeczenia, wyliczenia, antropomorfizacja, a także konsekwentne stosowanie dwóch (z czterech) głównych typów amplifikowania: uwypuklenia i kumulacji. Mnogość wskazanych zabiegów nie pozwala wątpić o celowości amplifikacyjnego wznoszenia ${ }^{12}$ Rymkiewiczowskiej opowieści o powstaniu warszawskim. W jej ramach - jak

12 Wzniosłość ta u wymienionych polskich pisarzy, biorąc pod uwagę ich skłonność do tematyzowania dziejów Rzeczypospolitej, jest chyba najbliższa Schillerowskiej konceptualizacji Erhabene, nieuchylającej się przed mariażem wzniosłego ze sferą historii (w przeciwieństwie np. do koncepcji Burke’a czy Kanta) (White 2014: 151-166). 
wiadomo - jednym z wątków jest kwestia przynależenia Rzeczypospolitej do UE. Analogiczne uwznioślające operacje łatwo wskazać w pisarstwie pozostałych wymienionych polskich twórców (zob. Czardybon 2018: 217-218).

4.

W świetle tych ustaleń można stwierdzić, że duch brexitu w polskiej literaturze, podobnie jak w przypadku brytyjskiego stronnictwa „proleavers”, uobecnił się pod postacią okraszonego wzniosłą, godnościową retoryką, eksploatującego wspólnotowe resentymenty zwrotu ku kategorii narodu ${ }^{13}$ i jego - obfitującej w traumy - przeszłości. Przeszłość ta i łączona z nią świetność dawnej Rzeczypospolitej na kartach książek Rymkiewicza et consortes, niezależnie od wzmiankowanych traumatycznych aspektów, jawią się jako obiekty tęsknoty (nostalgii). $\mathrm{W}$ tekstach tych polskich pisarzy można jednak zauważyć także przesunięcie względem brytyjskiego eurosceptycyzmu ${ }^{14}$. Wzmiankowana obrona narodowej tożsamości i tradycji, w ujęciu rodzimych twórców, nierzadko przedstawiana bywa jako akt oporu względem kulturowej homogenizacji i konsumpcjonizmu zachodniego świata (a więc też państw „starej” UE). Jest to wyczuwalne chociażby w przytoczonym cytacie $\mathrm{z}$ wiersza Polkowskiego. Tym samym narodowy thymos, stymulowany w pracach omawianych pisarzy, stanowić ma, rzec można, remedium na zjawisko powszechnej „erotyzacji” ${ }^{15}$.

Na koniec warto powrócić do ustaleń zawartych w książce Tożsamość pióra Fukuyamy. Amerykański badacz rozróżnia dwa rodzaje godnościowych postaw. W pierwszym - izotymii - tymotyczna potrzeba zaspokajana jest przez poczucie bycia postrzeganym jako "tak samo dobry” (Fukuyama 2019: 41). Druga megalotymia - oznacza tendencję „rozwijaną na fundamencie wyjątkowości”, której clou stanowi „,uznanie siebie samego [i swojej wspólnoty - M.C.] za lepszego od innych" (Fukuyama 2019: 14-15). Przedstawione w moim szkicu

13 Konceptualizacja kategorii narodu $\mathrm{w}$ wykonaniu polskich pisarzy czerpie niemało $\mathrm{z}$ tegoż „substancjalnej”, romantycznej wizji, odległej od np. Benedicta Andersona formuły „wspólnoty wyobrażonej” (Anderson 1997: 19). Piszą oni o „duchowym” wymiarze narodu i jego losów (zob. np. Rymkiewicz 2008: 186; Dakowicz 2014: 12).

14 Może ono wynikać z faktu, że Polska w xxı wieku, w przeciwieństwie do Wielkiej Brytanii, uznawana była głównie za beneficjenta wspólnotowej polityki „składkowej”.

15 „AAnimal eroticum» - jak celnie wskazuje Sloterdijk - to filozoficzna nazwa konsumenta, zaś Eros w tym rozumieniu oznacza prostą przemianę materii. Następuje dziś niesamowite i zagadkowe przekształcenie kultury, niegdyś inspirowanej arystokratyczną dumą, w rozerotyzowaną cywilizację młodszych i starych konsumentów" (Sloterdijk, Bielik-Robson 2007). 
uwagi uprawniają twierdzenie, że tendencja ta manifestuje się zarówno w stricte brexitowych debatach, jak i w deprecjonowaniu ue à la polonaise. Tym samym „postać” (i imię) ducha brexitu, zdarzenia-znaku, w którym przejawia się (?) obecny Zeitgeist, stanowi narodowa megalotymia.

Pozostaje pytanie o jej powody. Biorąc pod uwagę odmienność brytyjskich i polskich politycznych oraz dziejowych uwarunkowań, istnieje szansa, że wskazanie na doraźne zawirowania polityczne czy kontrowersje wokół - nękanej kryzysami - uE to zbyt mało, by wyjaśnić przyczyny narastającej (nie tylko w wymienionych krajach zresztą - zob. Pleśniarska 2017: 29-43) narodowej megalotymii. Jedną z możliwych interpretacji tego zjawiska jest hipoteza, że stanowi ono powrót - po latach „paraliżu” spowodowanego II wojną światową i jej żywym wspomnieniem - śmiałego dążenia, by przeciwstawić się, wzmożonej dodatkowo przez procesy globalizacyjne i technologiczny rozwój, „nieautentyczności” ludzkiego życia. Życia w „kryształowym pałacu”, zdominowanego przez ekonomiczną cyrkulację, kulturę masową itd. Dążenie to, mutatis mutantis, jest znane chociażby z pierwszych dekad xx wieku. Jak pisał Sloterdijk, uwidoczniło się ono np. w „wielkiej fenomenologii nudy” z Bycia i czasu. Na „głęboką nudę bytu pozbawionego wyzwań" - w ujęciu Martina Heideggera - składają się brak jakiegokolwiek obowiązującego przekonania i zbyteczność wszelkich osobistych decyzji.

W tym miejscu [...] - komentuje Sloterdijk - naświetlono dokładnie to, co później nazwano ze-stawem (Ge-stell) - przede wszystkim ze względu na nieautentyczną, pozbawioną siebie egzystencję. Gdzie każdy jest kimś innym, ale nigdy sobą samym, tam oszukano człowieka na jego ekstazie, na jego samotności, na jego decyzji, na jego bezpośredniej relacji do absolutnej zewnętrzności, do śmierci (Sloterdijk 2011b: 215).

W powyższym ujęciu XxI-wieczna megalotymia jawi się jako oparte na dziejowych resentymentach przyzywanie utraconej „autentyczności”, upatrywanej w narodowym żywiole. Rozpoznanie to poniekąd splata się z tezą Jeana Baudrillarda o powrocie „nowych integryzmów” jako zbiorowej reakcji na „rewolucję” postmodernej „hiperrealności” i związanej z nią bezwarunkowej, ale tė̇ „bezsensownej” (to jest pozbawionej wyzwań etc.) wolności (Baudrillard 2005: 42-44). Tu z kolei przydatne okazują się rozpoznania Zygmunta Baumana, dotyczące zauważalnego wzrostu postaw retrotopijnych w społeczeństwach doby późnej nowoczesności.

„Retrotopijny”, a więc dowartościowujący przeszłość ogląd rzeczywistości konstytuuje dążność do „rehabilitacji plemiennego modelu wspólnoty” 
z naciskiem na kwestię tożsamości jako remedium na poczucie zagrożenia i bezdomności człowieka we współczesnym świecie. „Przeszłość” ta jednak nie stanowi przeszłości par excellence. To nie „powrót” do tego, co było, lecz „iteracja status quo ante”, „którego obraz [...] został poddany znacznemu recyklingowi i modyfikacjom w naprzemiennych procesach wybiórczego zapamiętywania oraz wybiórczego zapominania" (Bauman 2018: 17-20). Wyjaśniałoby to zwrot ku narodowej tradycji (mylonej często z dziedzictwem ${ }^{16}$ ), a także kategoriom brytyjskości/polskości, zauważalny w wystąpieniach zwolenników brexitu, jak i polskich eurosceptyków. Ponieważ jednak - jak sygnalizowałem na początku specyfika Zeitgeistu rozpoznawalna bywa ex post, moje uwagi zawarte w tym szkicu należy potraktować jako materiał do przyszłych weryfikacji.

\section{| Bibliografia}

Anderson Benedict (1997), Wspólnoty wyobrażone. Rozważania o źródłach i rozprzestrzenianiu się nacjonalizmu, przeł. Stefan Amsterdamski, „Znak” i Fundacja im. Stefana Batorego, Warszawa-Kraków.

Baran Grzegorz M. (2018), Gniew Boży a gniew ludzki w świetle terminologii pierwszej i drugiej Księgi Machabejskiej, „Verbum Vitae”, nr 33, s. 59-92, https://doi.org/10.31743/vv.2018.33.04.

Baudrillard Jean (2005), Pakt jasności: o inteligencji zła, przeł. Sławomir Królak, Sic!, Warszawa.

Bauman Zygmunt (2018), Retrotopia: jak rządzi nami przeszłość, przeł. Karolina Lebek, Pwn, Warszawa.

Burke Kenneth (1969), Rhetorics of Motives, University of California Press, Berkeley/Los Angeles.

Cesarz Maciej (2017), Kryzys uchodźczy w Europie - zarys problemu, w: Uchodźcy w Europie - uwarunkowania, istota, następstwa, red. Konstanty A. Wojtaszczyk, Jolanta Szymańska, Aspra, Warszawa, s. 103-119.

16 Odwołując się chociażby do ustaleń Romana Zimanda, wypada stwierdzić, że tradycja stanowi swoisty wybór (konstrukt) z dziedzictwa (a więc całokształtu treści/materii kulturowej/historycznej itd., które niesie za sobą przeszłość - w omawianym przypadku danego narodu). Wybór ten dokonany zostaje „ze względu na to, jak jest” i ,jak chcemy, aby było". Tymczasem w retrotopijnych wizjach wyłaniających się z prac omawianych $\mathrm{w}$ tym szkicu pisarzy tradycja podlega naturalizacji. Innymi słowy - mylnie przypisane zostają jej właściwości dziedzictwa (Zimand 1967: 364). 
Chan Tak Wing i in. (2020), Understanding the social and cultural bases of Brexit*, "British Journal of Sociology", nr 5 (71), s. 830-851, https://doi.org/10.1111/1468-4446.1279o.

Czapliński Przemysław (2001), Wzniosłe tęsknoty: nostalgie w prozie lat dziewięćdziesiątych, Wydawnictwo Literackie, Kraków.

Czapliński Przemysław (2011), Resztki nowoczesności, Wydawnictwo Literackie, Kraków.

Czardybon Marcin (2018), Rzeczpospolita wzniosła. Zarys ekonomii resentymentalnej (o pisarstwie Jarosława Marka Rymkiewicza, Wojciecha Wencla i Przemysława Dakowicza), „Ruch Literacki”, z. 2 (347), s. 213-227, https://doi.org/10.24425/122701.

Dakowicz Przemysław (2014), Obcowanie. Manifesty i eseje, Sic!, Warszawa.

Eaglestone Robert (2018), Cruel Nostalgia and the Memory of the Second World War, w: Brexit and Literature. Critical and Cultural Responses, red. Robert Eaglestone, Routledge, London, s. 92-104.

Erll Astrid (2018), Kultura pamięci. Wprowadzenie, przeł. Agata Teperek, Wydawnictwo Uniwersytetu Warszawskiego, Warszawa.

Farage Nigel (2015), Believe in Britain, https://www.youtube.com/watch?v=OQi1I1TcrVA [dostęp: 15.03.2021]. Fukuyama Francis (2017), Koniec historii i ostatni człowiek, wstęp Piotr Kłodkowski, przeł. Tomasz Bieroń, Marek Wichrowski, Znak, Kraków. Fukuyama Francis (2019), Tożsamość: Współczesna polityka tożsamościowa i walka o uznanie, przeł. Jan Pyka, Dom Wydawniczy „Rebis”, Poznań.

Hill Geoffrey (1996), Canaan, Penguin, Harmondsworth.

Honneth Axel (2012), Walka o uznanie: moralna gramatyka konfliktów społecznych, przeł. Jakub Duraj, Zakład Wydawniczy „Nomos”, Kraków 2012.

Jung Theo (2014), The Politics of Time. Zeitgeist in Early Nineteen-Century Political Discourse, „Contribution to the History of Concept”, nr 9, s. 24-49, https://doi.org/10.3167/choc.2014.090102.

Koegler Caroline, Malreddy Pavan Kumar, Tronicke Marlena (2020), The colonial remains of Brexit, „Journal of Postcolonial Writing”, nr 5 (56), s. 585-592, https://doi.org/10.108o/17449855.2020.1818440.

Łabędź Krzysztof (2017), Postawy i poglady polskiego społeczeństwa sprzyjające „dobrej zmianie”, w: Współczesne oblicza władzy politycznej. Wybrane zagadnienia, red. Marcin Rachwał, Wydawnictwo Naukowe UAM, Poznań, s. $159-168$.

Pleśniarska Aleksandra (2017), Integracja europejska w obliczu eurosceptycyzmu, „Zeszyty Naukowe. Uniwersytet Ekonomiczny w Krakowie”, nr 6 (966), s. 29-43, https://doi.org/10.15678/ZNUEK.2017.0966.0602.

Polkowski Jan (2015), Gorzka godzina, Sic!, Warszawa.

Rymkiewicz Jarosław Marek (2008), Kinderszenen, Sic!, Warszawa. 
Self John (2020), How Brexit has reshaped the British Novel, „Penguin”, https://tinyurl.com/ahazh4sw [dostęp: 29.03.2021].

Shaw Kristian (2018), BrexLit, w: Brexit and Literature. Critical and Cultural

Responses, red. Robert Eaglestone, Routledge, Londyn, s. 15-31.

Shopenhauer Arthur (1908), O wolności ludzkiej woli, przeł. Adam

Stögbauer, red. Henryk Goldberg, E. Wende i Spółka, Warszawa, https://tinyurl.com/pfjzs6fn [dostęp: 1.04.2021].

Sloterdijk Peter (2011a), Gniew i czas. Esej polityczno-psychologiczny, przeł. Arkadiusz Żychliński, Wydawnictwo Naukowe Scholar, Warszawa.

Sloterdijk Peter (2011b), Kryształowy pałac: o filozoficzna teorie globalizacji, przeł. Borys Cymbrowski, Wydawnictwo Krytyki Politycznej, Warszawa.

Sloterdijk Peter, Bielik-Robson Agata (2007), O trudnym dojrzewaniu do szcześcia, „Dziennik”, https://tinyurl.com/5kvdka8k [dostęp: 2.04.2021].

Spiering Menno (2014), A Cultural History of British Euroscepticism, Palgrave Pivot, Londyn.

White Hayden (2014), Polityka interpretacji historycznej. Dyscyplina i de-sublimacja, przeł. Emilia Kledzik, przekład przejrzała Ewa Domańska, w: tenże, Przeszłość praktyczna, red. Ewa Domańska, Universitas, Kraków, s. 151-166.

Wencel Wojciech (2016), Epigonia, Arcana, Kraków.

Zimand Roman (1967), Problem tradycji, w: Proces historyczny w literaturze i sztuce, red. Maria Janion, Aniela Piorunowa, Państwowy Instytut Wydawniczy, Warszawa, s. 360-379.

\section{| Abstrakt}

\section{Marcin Czardybon}

O duchu (brexitu). $\mathrm{Z}$ dodatkiem uwag o tymotycznej stymulacji narodu w najnowszej polskiej literaturze

Artykuł stanowi próbę odpowiedzi na pytanie o obecność „ducha brexitu” w tekstach literackich powstających poza Wyspami. Pierwsza część poświęcona jest wyjaśnieniu sformułowania „duch brexitu” w świetle kategorii Zeitgeist. W drugiej partii tekstu wskazuję na zbieżności i różnice pomiędzy eurosceptycznymi nastrojami w brytyjskiej literaturze, a eurosceptycyzmem polskich xxI-wiecznych pisarzy, sytuujących się blisko prawej strony sceny politycznej. W myśl głównej tezy artykułu „duch brexitu” uobecnia się tak w brytyjskiej, jak i w polskiej literaturze w pracach dowartościowujących kategorię narodu, jego tradycji i dziejów. Prace te pobudzają godnościowe roszczenia i aktywizują narodowe resentymenty. Wykorzystane w szkicu ustalenia filologów, socjologów, filozofów i badaczy retoryki służą 
dowiedzeniu przedstawionej tezy, ukazaniu sposobów przejawiania się omawianego fenomenu oraz sformułowaniu odpowiedzi na pytanie o jego przyczyny.

Słowa kluczowe: Zeitgeist; brexit; nacjonalizm; thymos; resentyment

\section{| Abstract \\ Marcin Czardybon \\ On the Spirit (of Brexit): With Additional Remarks on the Thymotic Stimulation of the Nation in the Latest Polish Literature}

The article is an attempt to answer the question about the presence of the "Brexit spirit" in literary texts created outside the UK. The first part is devoted to explaining the term "Brexit spirit" in the light of the Zeitgeist category. In the second part, I point out the similarities and differences between the Eurosceptic moods in British literature and the Euroscepticism of Polish twenty-first-century right-wing writers. According to the main thesis of the article, the "Brexit spirit" is present in British and Polish literature in works that value the category of the nation, its traditions and history. These works stimulate dignity claims and activate national resentments. The findings of philologists, sociologists, philosophers and researchers of rhetoric used in the sketch serve to prove the presented thesis, to show the ways in which the discussed phenomenon manifests itself, and to formulate an answer to the question about its causes.

Keywords: Zeitgeist; Brexit; nationalism; thymos; resentment

\section{| Biogram}

Marcin Czardybon - dr, Uniwersytet Warszawski (Wydział Polonistyki). Zainteresowania naukowe: mity narodowe, związki polityki i literatury, filozofia. Najważniejsze publikacje: „Jeżeli mi nie wierzycie, to popatrzcie tu, na mój talerz”. Prawda konfabulacji w prozie reportażowej Curzia Malapartego, „Tekstualia” nr 4 (47), 2016; Rzeczpospolita wzniosła. Zarys ekonomii resentymentalnej (o pisarstwie Jarosława Marka Rymkiewicza, Wojciecha Wencla i Przemysława Dakowicza), „Ruch Literacki” 2 (347), 2018; Przenajświętsza. Szkic o sakralizacji wspólnoty narodowej w literaturze polskiej XXI wieku, „Teksty Drugie” 3, 2021.

E-mail: czardymar@gmail.com

ORCID: 0000-0002-5627-142X 